Bangladesh J. Sci. Ind. Res. 42(3), 361-365, 2007

Short Communication

\title{
Suitability of Different Cultivars of Wheat and Maize for Cultivation in Coastal Area of Noakhali
}

\author{
F. Begum, ${ }^{a}$ A. Sadeque, ${ }^{a}$ F. Khatun ${ }^{\mathrm{b}}$ and M. K. Alam ${ }^{\mathrm{b}}$ \\ ${ }^{a}$ Agronomy Division, Bangladesh Agricultural Research Institute, Joydevpur \\ and ${ }^{b}$ Breeding Division, BARI, Joydevpur, Bangladesh
}

\begin{abstract}
The experiment was conducted to screen the salt tolerant variety of maize and wheat at Atkapalia , Noakhali. The result shows that variety Gourav and Kanchan of wheat and Barnali and BARI Bhutta 5 of maize have better adaptability in saline areas of Noakhali. All the crops showed lower yield under salinity. The decrease in yield is attributed to the accumulation of sodium and chloride ions and a decrease in potassium ions. This conclusion is arrived at in the light of previous experimental results on the accumulation of sodium, chlorine and potassium ions in wheat and maize.
\end{abstract}

Key words :

\section{Introduction}

More than $30 \%$ of the net cultivable land in Bangladesh is in the coastal area (Karim et al, 1990). Some of these costal areas like Noakhali, Khulna, Potuakhali and Chittagong are seriously affected by various degrees of salinity (Karim et al.,1990). A country like Bangladesh, which is thickly populated with limited cultivable land is thus threatened by salinity. As a vast coastal area is gradually becoming uncultivable, efforts are needed to bring back the saline area under cultivation by selecting salt tolerant crops from amongst the existing practices as also by introducing new genotypes/varieties. An experimental set up to evaluate the crop varieties of maize and wheat suitable for coastal areas and the results obtained are reported.

\section{Materials and Methods}

The experiment was conducted in Atkapalia, Noakhali at FSR site BARI. Atkapalia Farming System Research site (FSR) is located in Noakhali district in southern-western part of the country and belong to Agroecological Zone (AEZ) 18f. Soil salinity test was carried out throughout the growing period (December to March) at a regular intervals of 15 days. Soil samples were 
collected at different depth such as $0-10 \mathrm{~cm}$, 10 - $20 \mathrm{~cm}$, and 20 - $30 \mathrm{~cm}$ deep. Four genotypes of wheat namely Gourav, Kanchan, Protiva and Sourav, and four cultivars of maize namely Barnali, BARI Bhutta 5, Khoibhutta and Pacific11, were grown in the coastal saline areas, to screen the suitable variety of maize and wheat. Seeds were collected from Wheat Research Centre and Breeding Division of BARI, Joydebpur, Gazipur.

To avoid the possible effect of variation in the soil condition the experiment was carried out using Randomized Complete Block Design (RCBD) with three replications. Crops were sown on 15th December 1999 and also 2000. Recommended fertilizer doses appropriate for wheat and maize were applied. The unit plot size was $4 \mathrm{~m} \times 3 \mathrm{~m}$ for wheat and it was $5 \mathrm{~m} \times 4.5 \mathrm{~m}$ for maize. Intercultural operation was followed as and when necessary. Yield and yield contributing data were recorded. Ten plants were randomly selected from each plot and tagged for recording height and other yield contributing characteristics. Yield data were recorded for whole plot basis and then converted to $\mathrm{kg} / \mathrm{ha}$. Yield and yield contributing characters were taken at harvest. Data were collected and statistically analyzed ( DMRT method ).

\section{Results and Discussion}

\section{Soil salinity and crop growth}

During the crop growth period, the soil salinity level at Atkapalia, Noakhali varied from 1.99 to $15.94 \mathrm{dS}^{\mathrm{m}}$ Salinity was low in all the experimental plots during the time of sowing with values of salinity 3.6, 3.4 and $3.0 \mathrm{dS}^{-\mathrm{m}}$ at depths $0-10 \mathrm{~cm}, 10-20 \mathrm{~cm}$ and 20-30 cm respectively (Table I).

The salinity however increased afterwards from $3.6 \mathrm{dS}^{-\mathrm{m}}$ to $5.88 \mathrm{dS}^{-\mathrm{m}}$ in the region $0-10$ cm deep, from $3.4 \mathrm{dS}^{-\mathrm{m}}$ to $3.49 \mathrm{dS}^{-\mathrm{m}}$ in the region 10-20 $\mathrm{cm}$ deep and $3.00 \mathrm{dS}-\mathrm{m}$ to 3.49 $\mathrm{dS}^{-\mathrm{m}}$ in the region 20-30 $\mathrm{cm}$ deep (Table I) in the month of January and maximum 15.94 dSm on mid February. This salinity increase was determined from the conductivity measurement which increases with increasing salinity because the conduction process is

Table I. Soil salinity at different depth of soil at the experimental field of Atkapalkia, Noakhali

\begin{tabular}{l|c|c|c}
\hline \multirow{2}{*}{ Date of samplings } & \multicolumn{3}{|c}{ Salinity level $\left(\mathrm{dS}^{-\mathrm{m}}\right)$ at different depth of soil } \\
\cline { 2 - 4 } & $0-10 \mathrm{~cm}$ & $10-20 \mathrm{~cm}$ & $20-30 \mathrm{~cm}$ \\
\hline $03-01-2000$ & 5.85 & 3.49 & 3.49 \\
$18-01-2000$ & 6.69 & 6.82 & 1.99 \\
$02-02-2000$ & 6.82 & 6.82 & 5.55 \\
$17-02-2000$ & 15.94 & 6.06 & 3.36 \\
$03-03-2000$ & 10.37 & 6.69 & 2.96 \\
\hline
\end{tabular}


carried out by the ions. Salinity increased with the time and reached peak at mid February at soil surface $(0-10 \mathrm{~cm})$. It was observed that salinity was higher at flowering stage and so the yield might have been affected by the increased salinity of the soil.

Yield performance of different varieties of maize and wheat cultivars in saline area of Atkapalia, Noakhali

All the crops shows lower yield than national average value. Among the different varieties of wheat, the observed difference in yield was significant. Variety Gaurav showed better performance than the other varieties. Gaurav gave significantly highest yield. Plant height was not sighificantly varied among the varieties. Maximum straw yield was observed in gaurav. Thousand grain yield was also highest in Gaurav. These results reflect that Gaurav has maximum yield. Grain yield of Gaurav was 1058 kg/ha which in case of both Sourav and Provati was $608 \mathrm{~kg} / \mathrm{ha}$. Plant height and yield attributed characteristics were not significantly influenced by the varieties tested (Table II).

Among the maize varieties grain yields were significantly varied. Length of cob and weights as taken for 1000 grains were significantly different (Table III). In case of maize Barnali showed highest plant height $(170.13 \mathrm{~cm}$.) and pacific showed lowest height which was $155 \mathrm{~cm}$. Among the varieties, considering plant height, no of cob/plant no of grain/cob, BARI Bhutta 5 and Barnali are least affected and Pacific 11 most affected in saline areas of Noakhali. 1000 grain wt is significantl higher in BARI Bhutta 5 and minimum in Khoibhutta The highest grain yield was observed in BARI Bhutta 5 (962.95kg/ha) which closely followed by Barnali. Pacific-11 showed minimum grain yield which was only $755 \mathrm{Kg} / \mathrm{ha}$. The maximum yield in case of BARI Bhutta 5 might he due to highest no. of cob/plant, no. of grain / cob and also due to higher 1000 grain wt.

Table II. Yield Performance of different wheat cultivars grown in saline area, Atkapali, Noakhali.

\begin{tabular}{l|l|l|l|l|l|l|l|l}
\hline Variety & $\begin{array}{l}\text { Plant } \\
\text { height } \\
(\mathrm{cm})\end{array}$ & $\begin{array}{l}\text { Ear } \\
\text { height } \\
(\mathrm{cm})\end{array}$ & $\begin{array}{l}\text { No.of } \\
\text { Spiklet } \\
\text { / spike }\end{array}$ & $\begin{array}{l}\text { No.of } \\
\text { grain } \\
\text { / spike }\end{array}$ & $\begin{array}{l}\text { No.of } \\
\text { tiller/ } \\
\text { plant }\end{array}$ & $\begin{array}{l}1000 \\
\text { grain } \\
\text { wt.(g) }\end{array}$ & $\begin{array}{l}\text { Straw } \\
\text { yield } \\
\text { (kg/ha) }\end{array}$ & $\begin{array}{l}\text { Grain } \\
\text { yield } \\
\text { (kg/ha) }\end{array}$ \\
\hline Gourav & 77.4 & 7.4 & 17.3 & 34.8 & 5.93 & $4.2 \mathrm{a}$ & 2.33 & $1058 \mathrm{a}$ \\
Kanchan & 77.3 & 6.8 & 19.0 & 35.9 & 6.70 & $4.1 \mathrm{a}$ & 1.77 & $775 \mathrm{~b}$ \\
Sourav & 76.0 & 6.7 & 19.7 & 35.8 & 6.70 & $3.5 \mathrm{c}$ & 1.87 & $608 \mathrm{c}$ \\
Protiva & 79.1 & 6.9 & 18.87 & 36.3 & 5.60 & $3.8 \mathrm{~b}$ & 1.73 & $608 \mathrm{c}$ \\
\hline & NS & NS & NS & NS & NS & & NS & \\
\hline
\end{tabular}


Table III. Yield performance of different maize cultivars grown in saline area, Atkapolia, Noakhali

\begin{tabular}{l|c|l|l|l|l|l}
\hline Variety & $\begin{array}{c}\text { Plant } \\
\text { height }(\mathrm{cm})\end{array}$ & $\begin{array}{l}\text { No. of } \\
\text { cob/plan }\end{array}$ & $\begin{array}{l}\text { Cob length } \\
(\mathrm{cm})\end{array}$ & $\begin{array}{l}\text { No.of } \\
\text { grain/ cob }\end{array}$ & $\begin{array}{l}\text { 1000 grain } \\
\text { weight }(\mathrm{g})\end{array}$ & $\begin{array}{l}\text { Grain Yield } \\
(\mathrm{kg} / \mathrm{ha})\end{array}$ \\
\hline Barnali & 170.13 & 1.60 & 10.40 & 362.00 & $18.73 \mathrm{~b}$ & $933.32 \mathrm{a}$ \\
Khoibhutta & 163.20 & 1.53 & 11.67 & 353.30 & $14.28 \mathrm{c}$ & $888.88 \mathrm{~b}$ \\
BARI Bhutta 5 & 161.30 & 1.60 & 10.83 & 364.50 & $21.63 \mathrm{a}$ & $962.95 \mathrm{a}$ \\
Pacific 11 & 155.00 & 1.40 & 10.50 & 345.00 & $17.60 \mathrm{~b}$ & $755.35 \mathrm{c}$ \\
\cline { 2 - 7 } & NS & NS & NS & NS & & \\
\hline
\end{tabular}

The hybrid maize Pacific 11 gave minimum yield and showed maximum susceptibility to salinity (Table III).

From the experimental result, it concluded that variety Gourav and Kanchan of wheat could be cultivated in saline area of Noakhali with reasonable yield. Maize varieties BARI Bhutta 5 and Barnali showed better adaptability in saline areas of Noakhali.

Salinity caused an increase in accumulation of $\mathrm{Na}^{+}$and $\mathrm{C1}^{-}$and a decrease in accumulation of $\mathrm{K}^{+}$. It was reported that $\mathrm{Na}: \mathrm{K}$ ratio in plants is positively correlated with salinity and negatively correlated with yield (Ahmad et al. 1989). From the previous work, it was found that salinity increases $\mathrm{Na}^{+}$and $\mathrm{C1}^{-}$ions in maize, and also in wheat but decreases $\mathrm{K}^{+}$ ions in these crops (Begum and Karmoker, 1997; Begum et. al. 2000). So, the decrease in yield in maize and wheat grown in the coastal areas may be explained as due to increased accumulation of $\mathrm{Na}^{+}$and $\mathrm{Cl}^{-}$and a decrease in $\mathrm{K}^{+}$content.
A decrease in yield under salinity condition is also reported in chickpea (Lauter and Munns, 1966) and in finger millet (Onkware, 1993).

This decrease in yield of maize and wheat may be attributed to a decrease in chlorophyll content (Begum et al, 1997), and a decrease in dry matter (Begum et al. 1997, 2000) and leaf area (Zhaw, 1989)

A decrease in yield was also observed in green gram (Patil et al. 1992) with increasing salinity higher salinity level reduced paddy yield (Ahmed et al. 1989). Ahmad and his co-workers, 1989 reported that Na. K ratio is negatively correlated with yield. In the present experiment the observed decreased in yield under salinity can be attributed to an increase in the $\mathrm{Na}^{+} \& \mathrm{~K}^{+}$ratio accumulate in the plants due to saline environment in keeping with the previous results of Begum and Karmoker, 1997 on wheat and Begum et. al. 2000 on maize.

From the experimental investigation of the performance of different varieties of wheat 
and maizein the saline aera, it is found that the variety gaurav of wheat is most suitable for saline zone.In case of maize, the most suitable varieties are barnali and BARI bhutta 5. It can thus be concluded that these varieties of wheat and maize can profitably be cultivated in the coastal area, Atkapalia, Noakhali.

\section{References}

Ahmed, U.I. Faiz, S.M.A Anwar, A.K.M. and Sattar, A. (1989) Relation of Na/k ratio of rice with salinity and yield. Current Agriculture 13(1-2) : 73-78.

Begum, F. Sarker, B.C. and Hoque, S. (2000) Effect of salinity on growth and accumulation of $\mathrm{Na}^{+}, \mathrm{K}^{+}$and $\mathrm{Cl}^{-}$in maize (Zea mays). Dhaka Univ. J. Biol. Sci. 9(2) : 193198.

Begum, F. and Karmoker, J.L. (1997). The effect of $\mathrm{NaCl}$ on the growth, yield and mineral composition of Triticum aestivum L. J. Natl. Bot. Soc. 51 : 69-74.

Karim, Z. Hussain, S.G and Ahmed, M. (1990) Salinity problem and crop intensification in coastal region of Bangladesh. BARC soil Pulication No. 33.8. pp. 63.
Lauter, S.J and Munns, D.N. (1966). Salt resistance of chickpea genotype in solution salinized with $\mathrm{NaCl}$ or $\mathrm{Na}_{2} \mathrm{SO}_{4}$. Plant and Soil 95 : 271-279.

Onkware, A.O. (1993). The germination, growth and grain production of salt stressed finger millet (Eleusine coracana). Indian J. Plant Physiol 36(2) :77-81.

Patil, C.S. Hunshal, D.P. Viswanath, Chimmad, V.P. Salinath, S.B. and Hosmani, R.M. (1992). Effect of saline water irrigation on soil properties. Indian J. Maharastra Agric. univ. 17(2) : 229-231.

Zhaw, K.F. (1989) Mechanism of inhibitory effect of $\mathrm{NaCl}$ on the growth of satton seedlings Acta Phytophysiological Sinica 15(2) :173178

Received : February 28, 2007;

Accepted : August 13, 2007 